\title{
Nutritional value of breast and thigh muscle of chukar partridge (Alectoris chukar) under intensive fattening conditions
}

\author{
Radovan Jůzl ${ }^{1}$, Pavel Suchý ${ }^{1}$, Eva Straková ${ }^{1}$, Lucie Rusníková1, Miroslav Macháček ${ }^{1}$, \\ Petr Marada ${ }^{2}$ \\ ${ }^{1}$ University of Veterinary and Pharmaceutical Sciences Brno, Faculty of Veterinary Hygiene and Ecology, \\ Department of Nutrition, Animal Husbandry and Animal Hygiene, Brno, Czech Republic \\ ${ }^{1}$ Mendel University in Brno, Faculty of Agronomy, Department of Agriculture, Food and Environmental \\ Engineering, Brno, Czech Republic
}

Received January 10, 2012

Accepted July 16, 2012

\begin{abstract}
The aim of our study was to evaluate the nutritional value of the breast and thigh muscle of chukar partridge (Alectoris chukar) under intensive fattening conditions. Commercial feeding mixtures for broilers were used. Live weight of 60 partridges (birds were not sexed) was controlled during 90 days of fattening. After the fattening was finished, 30 birds were selected to monitor the carcass yield. Breast and thigh muscle were used for chemical analysis of crude protein (Kjeldahl method), total lipids (fat analyser $\mathrm{ANKOM}^{\mathrm{XT10}}$ ), ash (Muffle furnace - 550 ${ }^{\circ} \mathrm{C}$ ) and gross energy (calorimetry). Average values of live weight were increasing in the course of fattening; at the end of fattening the live weight reached $0.452 \mathrm{~kg}$. The carcass yield, breast muscle yield and thigh yield were evaluated $(73.72 \%, 18.09 \%, 20.80 \%$, respectively). Chemical analysis showed a highly significant difference $(P \leq 0.01)$ between the breast and thigh muscle for crude protein, fat, ash and gross energy. The ash content demonstrated a significant difference $(P \leq 0.05)$ between the breast and thigh muscle. This study brings new data on the nutritional value of the meat of chukar partridge that can be used for reccomendation of a suitable feeding mixture.
\end{abstract}

Meat, chemical analysis, carcass yield, feathered game

Chukar partridges (Alectoris chukar) are kept only for hobby purposes. At present, we have little knowledge about the nutrition of partridges. Partridges are not bred for intensive fattening and no feeding mixtures are produced for such purposes. There are only feeding mixtures that do not reflect the exact nutrient and energy demands of rearing birds. Research on the breeding and fattening of partridges is limited compared to other species of birds, although the interest in their meat for human consumption rises (Gulsen et al. 2010).

An optimal composition of the feeding mixture is monitored and recommended ( $\mathrm{Cu}$ fadar et al. 2010a,b; Ozek et al. 2003; Ozek 2004; Ozek 2006). Other authors monitored chukar partridge growth in captivity (Balcioglu et al. 2009; Ozek et al. 2004a). Vitula et al. (2011) determined the gross energy in breast and thigh muscles in different species of feathered game including the chukar partridge. Gulsen et al. (2010) studied the addition of sunflower oil to the diet of growing partridges. Nevertheless, information on the nutritional value of partridge meat is missing. It is expected that intensive fattening will be introduced for chukar partridge, because of the growing interest in this type of breeding. There is a need to know the specific values of partridge body composition.

The aim of this study was to monitor the effect of intensive fattening on the quality of meat of chukar partridge.

\section{Materials and Methods}

Meat samples from partridges, namely thigh and breast muscle were used in this study. These samples originated from a biological experiment which was carried out in an experimental barn of the Department of Nutrition, Animal Husbandry and Animal Hygiene, University of Veterinary and Pharmaceutical Sciences

Address for correspondence:

Mgr. Lucie Rusníková

Department of Nutrition, Animal Husbandry and Animal Hygiene

Faculty of Veterinary Hygiene and Ecology

University of Veterinary and Pharmaceutical Sciences Brno

Palackého tř. 1/3, 61242 Brno, Czech Republic

Phone: +420541562674

E-mail: rusnikoval@vfu.cz

http://actavet.vfu.cz/ 
Brno. The experiment was conducted on 60 birds (birds were not sexed) of chukar partridge and took place under a specified lighting regime ( $23 \mathrm{~h}$ of light $+1 \mathrm{~h}$ of darkness) with housing on litter.

Experimental animals were fed with complete feeding mixtures commercially available for fattening broiler chickens (BR 1, BR 2 and BR 3). Feeding mixtures were applied according to the following scheme: BR 1 from the $1^{\text {st }}$ day till the $20^{\text {th }}$ day of age, BR 2 from the $20^{\text {th }}$ day till the $81^{\text {st }}$ day of age and BR 3 from the $81^{\text {st }}$ day to $90^{\text {th }}$ day of age. Dry matter composition of feeding mixtures was as follows: BR 1 contained crude protein (CP) $235.4 \mathrm{~g} \cdot \mathrm{kg}^{-1}$, fat $47.8 \mathrm{~g} \cdot \mathrm{kg}^{-1}$, ash $58.9 \mathrm{~g} \cdot \mathrm{kg}^{-1}$ and metabolizable energy (ME) $13.6 \mathrm{MJ} \cdot \mathrm{kg}^{-1}$, BR 2 contained CP $244.9 \mathrm{~g} \cdot \mathrm{kg}^{-1}$, fat $100.1 \mathrm{~g} \cdot \mathrm{kg}^{-1}$, ash

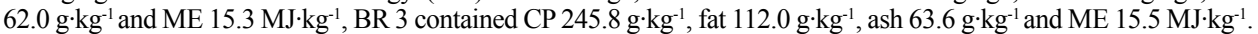
Partridges were fed ad libitum and all types of feeding mixtures were granulated. In the course of the fattening period, all experimental animals were checked for their live weight, namely on the $1^{\text {st }}, 11^{\text {th }}, 20^{\text {th }}, 29^{\text {th }}, 40^{\text {th }}, 50^{\text {th }}, 60^{\text {th }}, 70^{\text {th }}$, $81^{\text {st }}$ and $90^{\text {th }}$ days of age. On the $90^{\text {th }}$ day of age, 30 birds were slaughtered and checked for selected indicators (\%): the carcass yield $(n=30$ samples), breast muscle yield $(n=29)$ and thigh yield $(n=30)$. These data were obtained by weighing and calculation. Thirty samples of breast muscles and thirty samples of thigh muscles were analyzed with regard to its dry matter content $\left(\mathrm{g}^{\mathrm{kg}} \mathrm{kg}^{-1}\right)$; subsequently, the dry matter was analyzed with respect to the following indicators: crude protein $\left(\mathrm{g} \cdot \mathrm{kg}^{-1}\right)$, fat $\left(\mathrm{g} \cdot \mathrm{kg}^{-1}\right)$, ash $\left(\mathrm{g} \cdot \mathrm{kg}^{-1}\right)$, calcium Ca $\left(\mathrm{g} \cdot \mathrm{kg}^{-1}\right)$, phosphorus $\mathrm{P}\left(\mathrm{g} \cdot \mathrm{kg}^{-1}\right)$, magnesium $\mathrm{Mg}\left(\mathrm{g}^{\mathrm{kg}} \mathrm{g}^{-1}\right)$ and gross energy $\left(\mathrm{MJ}^{\mathrm{kg}} \mathrm{kg}^{-1}\right)$. After determining the pre-dry and dry matter, the sample was homogenized and then subjected to further analyses. The nitrogen content was determined according to Kjeldahl using the Büchi Kjeldahl apparatus (Centec automatika, spol. s.r.o., Czech Republic). The crude protein content was expressed in the sample by multiplying with the factor of 6.25 . Fat was determined through the use of ANKOM ${ }^{\mathrm{XT} 10}$ Fat Analyzer (O.K. Servis BioPro, Czech Republic). Ash was determined by weight after incineration at $550^{\circ} \mathrm{C}$ in a muffle furnace under prescribed conditions. Phosphorus, calcium and magnesium were determined from the sample ash according to CSN 467092-11,12,13. Calcium and magnesium were determined by leaching and subsequent titration and phosphorus by HELIOS $\alpha$ spectrophotometer (Thermo Stientific, England). Gross energy was measured at AC 500 calorimeter (Leco, USA).

Statistical evaluation of chemical analysis results were carried out using the Unistat program (5.6 for Excel), at the level of significance being $P \leq 0.01$ (a highly significant difference) and $P \leq 0.05$ (a significant difference).

\section{Results}

Fig. 1 shows the results of monitoring the body weight $(\mathrm{kg})$ during the fattening of partridges from the $1^{\text {st }}$ day till the $90^{\text {th }}$ day of their age. The live weight was increasing throughout the fattening period whereas the increase was not so expressive in the final stage. Deviations from the average body weight grew together with the weight. No animals died during the experiment.

Furthermore, we monitored the carcass yield in the experimental animals. The carcass yield at slaughter age of 90 days was $73.7 \%(n=30)$, breast muscle yield was about $18.1 \%$ $(\mathrm{n}=29)$ and thigh yield was $20.8 \%(\mathrm{n}=30)$.

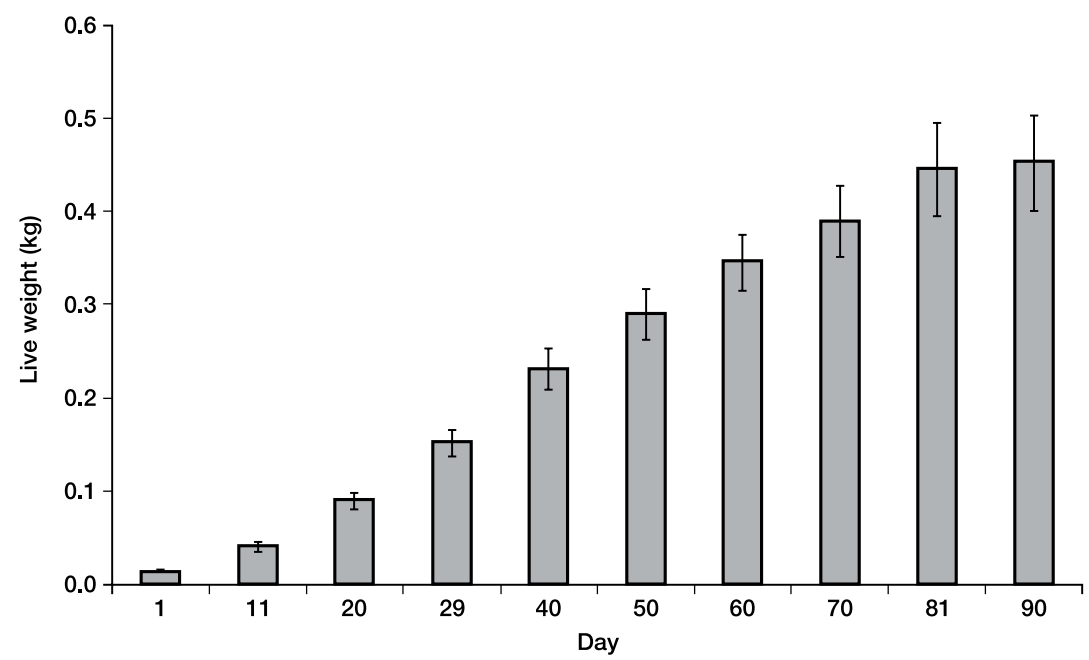

Fig. 1. Body weight development during the fattening of chukar partridge 
Table 1. Chemical analysis of the partridge breast and thigh muscle in $100 \%$ dry sample $\left(\mathrm{g} \cdot \mathrm{kg}^{-1}\right)$

\begin{tabular}{llc}
\hline Chemical indices & Sample & $\mathrm{x} \pm \mathrm{SD}$ \\
\hline Dry matter* & Breast & $272.75 \pm 14.17^{\mathrm{a}}$ \\
& Thigh & $260.44 \pm 8.99$ \\
$\mathrm{CP}\left(\mathrm{g} \cdot \mathrm{kg}^{-1}\right)$ & Breast & $922.54 \pm 28.34^{\mathrm{a}}$ \\
& Thigh & $845.32 \pm 25.75$ \\
Fat $\left(\mathrm{g} \cdot \mathrm{kg}^{-1}\right)$ & Breast & $17.59 \pm 11.55^{\mathrm{a}}$ \\
& Thigh & $97.70 \pm 30.55$ \\
Ash $\left(\mathrm{g} \cdot \mathrm{kg}^{-1}\right)$ & Breast & $46.33 \pm 1.04^{\mathrm{a}}$ \\
& Thigh & $49.36 \pm 1.77$ \\
$\mathrm{Ca}\left(\mathrm{g} \cdot \mathrm{kg}^{-1}\right)$ & Breast & $2.44 \pm 0.50^{\mathrm{b}}$ \\
& Thigh & $2.18 \pm 0.49$ \\
$\mathrm{P}\left(\mathrm{g} \cdot \mathrm{kg}^{-1}\right)$ & Breast & $8.75 \pm 0.30^{\mathrm{NS}}$ \\
& Thigh & $8.78 \pm 0.56$ \\
$\mathrm{Mg}\left(\mathrm{g} \cdot \mathrm{kg}^{-1}\right)$ & Breast & $1.29 \pm 0.19^{\mathrm{NS}}$ \\
& Thigh & $1.32 \pm 0.26$ \\
$\mathrm{GE}\left(\mathrm{MJ}^{\mathrm{k}} \mathrm{kg}^{-1}\right)$ & Breast & $21.21 \pm 0.32^{\mathrm{a}}$ \\
& Thigh & $22.50 \pm 0.70$ \\
\hline
\end{tabular}

* In the original sample mass $\left(\mathrm{g} \cdot \mathrm{kg}^{-1}\right), \mathrm{CP}$ - crude protein, $\mathrm{GE}$ - gross energy, number of samples analyzed - 30, ${ }^{\text {a significant }}$ differences between groups $(P \leq 0.01)$, ${ }^{\text {b }}$ significant differences between groups $(P \leq 0.05)$, NS - non-significant difference and thigh muscles. In the dry matter, the breast muscle contained by $5.7 \%(P \leq 0.01)$ less gross energy than the thigh muscle.

\section{Discussion}

Feeding mixtures for broiler chickens were used to fatten the partridges; these mixtures contained higher levels of energy as well as crude protein compared to recommendations provided by Ozek et al. (2003). Also Cufadar et al. (2010a) recommended a diet with lower values ( $13 \%$ and $10.9 \mathrm{MJ}^{\mathrm{kg}}{ }^{-1}$ for $\mathrm{CP}$ and energy, respectively), than were used in our experiment. Higher energy amount could have an effect on the higher carcass yield, breast muscle and thigh muscle weight but it should not affect the live weight, weight gain, carcass properties, feed consumption and conversion (Ozek et al. 2003; Ozek 2004; Cufadar et al. 2010a).

Ozek (2006), however, discovered the influence of a higher CP amount (28\%) in the diet on the body weight which decreases with high protein concentrations. Such influence cannot be observed as regards our chosen diet (24\% of CP); live weight reached higher values in this period. In their study the partridge weight ranged as follows: $279 \mathrm{~g}(28 \%$ of CP), $280.4 \mathrm{~g}$ (18\% of CP), $286.1 \mathrm{~g}$ (26\% of CP), $298.9 \mathrm{~g}$ ( $22 \%$ of CP), $304.1 \mathrm{~g}(24 \% \mathrm{of}$ $\mathrm{CP})$ and $307.4 \mathrm{~g}(20 \%$ of CP).

Vitula et al. (2011) reported lower dry matter content values for the breast muscle in chukar partridges $\left(271.93 \pm 10.68 \mathrm{~g} \cdot \mathrm{kg}^{-1}\right)$ compared to dry matter content values for the thigh muscle $\left(274.75 \pm 18.03 \mathrm{~g} \cdot \mathrm{kg}^{-1}\right)$. They also determined higher value of gross energy $\left(23.03 \pm 0.57 \mathrm{MJ} \cdot \mathrm{kg}^{-1}\right.$ and $24.22 \pm 0.85 \mathrm{MJ} \cdot \mathrm{kg}^{-1}$ for breast and thigh muscle, respectively) in dry matter compared to results from our study, and also the gross fat $\left(40.64 \pm 24.68 \mathrm{~g} \cdot \mathrm{kg}^{-1}\right.$ and $161.40 \pm 86.98 \mathrm{~g} \cdot \mathrm{kg}^{-1}$ for breast and thigh muscle, respectively) reached higher values in their experiment than in our study. The CP $(924.37 \pm$ 
$31.11 \mathrm{~g} \cdot \mathrm{kg}^{-1}$ and $811.96 \pm 53.55 \mathrm{~g} \cdot \mathrm{kg}^{-1}$ for breast and thigh muscle, respectively) value reported by Vitula et al. (2011) corresponded to values obtained in our study.

Gulsen et al. (2010) studied 12-week-old chickens fed a diet without soybean oil in one group and with addition of oil in the second group. They determined body weight (439.75 g), carcass weight (318.81 g), thigh weight $(99.21 \mathrm{~g})$, breast weight (107.53 g) and carcass yield $(72.52 \%)$ in the group without addition of soybean oil. With the addition of oil to the diet, organ weights remained the same except for abdominal fat in their study. The body weight, carcass performance and weight of wings and breasts decreased linearly. Thigh and neck weights were not affected by adding oil to the diet according their results. Compared to our study, the partridges reached higher average body weight values on the $84^{\text {th }}$ day of age than stated by Gulsen et al. (2010). Even the value of carcass yield was higher according to our results; however, lower yield values were obtained with respect to the breast muscles and thigh in our study.

We therefore tried to compare the quality of partridge meat with the quality of meat from broiler and pheasant chickens; a noticeable difference can be seen in the meat composition.

Straková et al. (2011) dealt with comparing the meat from broiler chickens (fattening until the $40^{\text {th }}$ day of age) and pheasant chickens (fattening until the $90^{\text {th }}$ day of age). Suchý et al. (2002) studied the composition of breast and thigh muscle in hens and roosters of broiler chickens in the $42^{\text {nd }}$ and $52^{\text {nd }}$ day of fattening. Več erek et al. 2005 studied variation in the chemical composition of muscles in young pheasants during their growth.

Compared with results of Straková et al. (2011) and Suchý et al. (2002), results of this study show that the partridge meat contains less CP in the breast muscle than pheasant but more than broiler. As for the thigh muscle, it contains more $\mathrm{CP}$ than pheasant and broiler. Partridge thigh muscle contains less fat than the thigh muscle of pheasant and broiler. The amount of ash in breast and thigh muscles of partridges is comparable with the muscle of pheasant; partridge muscle contains the highest quantity of calcium and the lowest amount of magnesium. The amount of phosphorus in the partridge muscle is lower than in the muscle of pheasant (Suchý et al. 2002; Straková et al. 2011). The breast and thigh muscle of pheasant contains more CP and phosphorus, and less fat and calcium, compared to broiler chickens (Večerek et al. 2005). Gross energy content in the breast and thigh muscles is the lowest in partridge $\left(23.0 \mathrm{MJ} \cdot \mathrm{kg}^{-1}\right.$ and $24.2 \mathrm{MJ} \cdot \mathrm{kg}^{-1}$ for breast and thigh muscle, respectively) followed by pheasant $\left(23.1 \mathrm{MJ}^{-1} \mathrm{~kg}^{-1}\right.$ and $25.3 \mathrm{MJ} \cdot \mathrm{kg}^{-1}$ for breast and thigh muscle, respectively), the highest values of gross energy are achieved in broiler (23.8 $\mathrm{MJ} \cdot \mathrm{kg}^{-1}$ and $27.3 \mathrm{MJ} \cdot \mathrm{kg}^{-1}$ for breast and thigh muscle, respectively). In all species, higher gross energy values were found in the thigh muscle (Vitula et al. 2011).

The results of our study show the difference between breast and thigh muscles of partridges, both in the carcass yield and chemical analysis. The breast muscle could be considered a more valuable part of the partridge carcass because it contains higher amounts of CP and less fat than thigh muscles (as in the case of broiler or pheasant).

This finding ranks the partridge meat among the nutritionally valued feathered game meat. Results obtained are also interesting due to the fact that no special feeding mixtures for partridges or special breeding methods to improve carcass yield and meat quality were used. Partridges were fed under intensive conditions. It can be assumed that the improvement of these aspects could improve the nutritional value of chukar partridge meat.

\section{Acknowledgements}

This study was funded by the grant IGA 78/2011/FVHE.

\section{References}

Balcioglu MS, Kizilkaya K, Karabag K, Alkan S, Yolcu HI, Sahin E 2009: Comparison of growth characteristics of chukar partridges (Alectoris chukar) raised in captivity. J Appl Anim Res 35: 21-24 
Cufadar Y, Olgun O, Bahtiyarca Y, Yildiz AO 2010a: Effects of dietary energy and protein on performance, reproduction traits and nitrogen-excretion of breeder chukar partridges (Alectoris chukar). Rev Med Vet 161: $151-156$

Cufadar Y, Olgun O, Bahtiyarca Y, Yildiz AO 2010b: Effects of dietary energy content on the performance and laying traits of the breeder chukar partridge (Alectoris chukar) housed in battery cages or litter floor pens. Rev Med Vet 161: 99-103

ČSN 46 7092-11: Metody zkoušení krmiv - Č́st 11: Stanovení obsahu celkového fosforu. Praha: Český normalizační institut, 1998. ICS 65.120

ČSN 46 7092-12: Metody zkoušení krmiv - Část 12: Stanovení obsahu vápníku. Praha: Český normalizační institut, 1998. ICS 65.120

ČSN 46 7092-13: Metody zkoušení krmiv - Část 13: Stanovení obsahu hořčíku. Praha: Český normalizační institut, 1998. ICS 65.120

Gulsen N, Umucalilar HD, Kirikci K, Hayirli A, Aktumsek A, Alasahan S 2010: Sunflower oil supplementation alters meat quality but not performance of growing partridges (Alectoris chukar). J Anim Physiol Anim Nutr 94: 196-203

Ozek K 2004: Effect of energy level in the diet on body weight, feed consumption and feed conversion ratio at early growth period in the chukar partridge (Alectoris chukar chukar) raised in closed confinement. Rev Med Vet 155: 163-166

Ozek K 2006: The optimum protein content in high energy starter diet for chukar partridge (Alectoris chucar chucar). Int J Poultry Sci 5: 522-525

Ozek K, Bahtiyarca Y 2004: Effects of sex and protein and energy levels in the diet on the blood parameters of the chukar partridge (Alectoris chukar). Brit Poultry Sci 45: 290-293

Ozek K, Yazgan O, Bahtiyarca Y 2003: Effects of dietary protein and energy concentrations on performance and carcase characteristics of chukar partridge (Alectoris chukar) raised in captivity. Brit Poultry Sci 44: 419-426

Straková E, Suchý P, Karásková K, Jámbor M, Navrátil P 2011: Nutritional value of pheasant meat and its comparison with the meat of broiler chickens. Acta Vet Brno 80: 249-254

Suchý P, Jelínek P, Straková E, Hucl J 2002: Chemical composition of muscles of hybrid broiler chicken during prolonged feeding. Czech J Anim Sci 47: 511-518

Večerek V, Suchý P, Straková E, Vitula F, Mikundová M 2005: Variation in the chemical composition of muscles in young pheasants during their growth. Arch Tierzucht 48: 290-298

Vitula F, Suchy P, Strakova E, Karaskova K, Zapletal D, Kroupa L 2011: Energy value of meat in selected species of feathered game. Acta Vet Brno 80: 197-202 